\title{
Comparison on Soft Storey Effect at Different Level in Multi-Storey Buildings
}

\author{
Aye Thet Mon \\ Department of Civil \\ Engineering \\ Technological University \\ Thanlyin, Myanmar
}

\author{
Kyaw Zeyar Win \\ Department of Civil \\ Engineering \\ Technological University \\ Thanlyin, Myanmar
}

\author{
Ni Ni Moe Kyaw \\ Department of Civil \\ Engineering \\ Technological University \\ Thanlyin, Myanmar
}

\begin{abstract}
Nowadays, according to social and functional needs, various types of multi-storey or high rise buildings are the mostly useable buildings in many towns and cities. Among them, some buildings are constructed as soft storey because of the space occupancy considerations. The soft storey has one level that is considerably greater flexible than the storey above and below it. This type of building has no masonry wall in this level or it can also have a greater height than the rest of the floors. Generally, the soft storey usually exists at the ground floor level but it can form any level of a high-rise building to fulfill necessity. In this study, analysis and design of superstructure for twelve-storey reinforced concrete building are presented. Analysis and design of superstructure of the selected building are carried out by using Extended Three Dimensional Analysis of Building Systems software. Firstly, the model is analysed by using software. For the superstructure, storey drift limitation, P- $\Delta$ effect, overturning, storey shear and torsional irregularities are carried out from design results. Secondly, the structural designs are made by change of storey height and without change of structural element size, seismic zone, exposure type and soil type. Finally, storey drift of all storey levels and the analysis results of structural performance are compared.
\end{abstract}

Keywords: multi-storey; soft storey; storey drift; P- $\Delta$ effect; overturning; torsional irregularities.

\section{INTRODUCTION}

All over the world, the multi-storey buildings are widely used due to the rapid growth of the urban population, the high cost of land, and potential of popularity in which the provision of soft storey is a common practice. Generally, the soft storey usually exists at the ground floor level and is known as a soft storey building or an open ground storey building. As per Indian standard code of practice, a soft storey has stiffness less than 70 percent of the storey immediately above, or less than 80 percent of the average stiffness of the three storeys above. If the stiffness of the storey meets at least one of above two criteria, the structure is considered to have a soft storey. Nowadays, some space need to be wider open space and higher floor level are considered for the purpose of a large meeting room, a showroom or a banking hall etc. Therefore, soft storey can form any level of a high-rise building. Some buildings are regarded with typical height and designed for same typical floors in structural design. But in practice, height is suddenly increased in one floor and structural elements for this changed height are not designed again. These structures can get soft storey effect and the effect of the seismic loading becomes more severe for heights above this floor level. When the lateral force acts on soft storey building, the building might become failure due to its less stiffness because the seismic force distribution is dependent on the distribution of stiffness and mass along the height. In this study, the structural designs are made by change of storey height and without change of structural element sizes, seismic zone, exposure type and soil type. The structural elements are designed to resist not only gravity forces but also lateral forces including earthquake and wind loads. The mostly failure of soft storey effect on the world are mainly due to the earthquake because the structural members are not strong enough to hold up the building during an earthquake. This indicate that those buildings possess storeys that are significantly weaker or more flexible than adjacent storeys and where deformations and damage tend to be concentrated. The Figure.1 is the soft storey failure in M7.4 earthquake, Tukery, August 17, 1999.

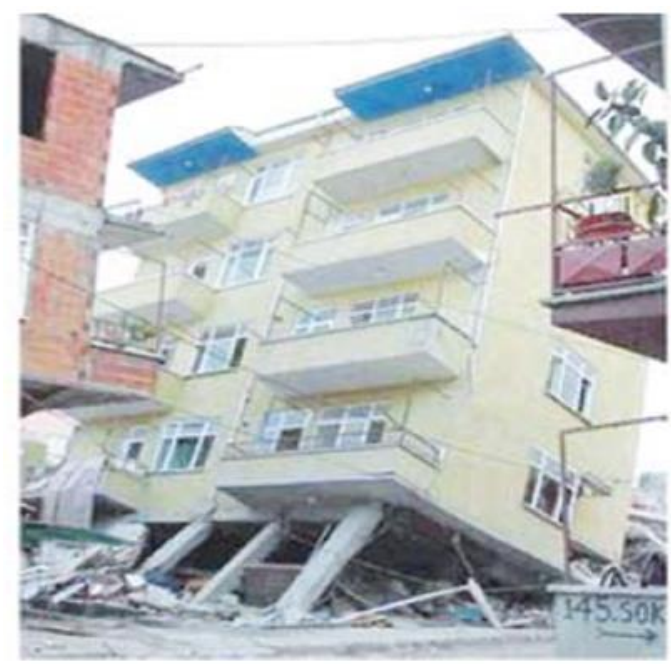

Figure.1 Soft storey failure in Tukery

\section{METHODOLOGY}

In this paper, The 12 multi-storey building will be analysed and designed by using Extended Three Dimensional Analysis of Building Systems (E-tabs) Software. All reinforced concrete members are designed with ultimate strength design using building code of American Concrete Institute (ACI) 318-99. Wind and earthquake loads are considered according to Uniform Building Code (UBC-1997). Exposure type (B) and soil type (D) are considered with design wind velocity 
$120 \mathrm{mph}$. Structural system is considered by concrete intermediate moment-resisting frame with over-strength factor 5.5. Firstly, the proposed model is statically analyzed and the structural elements of all storey levels will be compared to know whether or not soft storey effect for proposed buildings. And then, the results are carried out for the superstructure of the proposed model and finally these are compared.

\section{TYPE OF STRUCTURE}

\subsection{Data Preparation}

The following Tables describe the design data for five models having different geometrical configurations. Table 1 shows material specifications, Table 2 shows structural configurations, Table 3 shows different cases of five models, Table 4 shows storey heights of different configuration and Table 5 shows structural element sizes.

Table 1. Material specifications

\begin{tabular}{|c|c|}
\hline Concrete compressive strength $\left(\mathrm{f}_{\mathrm{c}}{ }^{\prime}\right)$ & $4 \mathrm{ksi}$ \\
\hline Reinforcing yield strength $\left(\mathrm{f}_{\mathrm{y}}\right)$ & $50 \mathrm{ksi}$ \\
\hline Modulus of Elasticity & $3605 \mathrm{ksi}$ \\
\hline Poisson's ratio & 0.2 \\
\hline
\end{tabular}

Table 2. Structural configurations

\begin{tabular}{|c|c|}
\hline Number of stories & 12 \\
\hline Width of structure & $68^{\prime}-0^{\prime \prime}$ \\
\hline Length of structure & $95^{\prime}-0^{\prime \prime}$ \\
\hline Total height of structure & $148^{\prime}-0^{\prime \prime}$ \\
\hline Number of bay's along X & 8 \\
\hline Number of bay's along Y & 6 \\
\hline
\end{tabular}

Table 3. Different cases of five models

\begin{tabular}{|c|c|}
\hline Model-1 & Conventional \\
\hline Model-2 & Soft storey at ground floor \\
\hline Model-3 & Soft storey at first floor \\
\hline Model-4 & Soft storey at second floor \\
\hline Model-5 & Soft storey at third floor \\
\hline
\end{tabular}

Table 4. Storey heights of different configuration

\begin{tabular}{|c|c|c|c|c|c|}
\hline \multirow{3}{*}{ Storey } & \multicolumn{5}{|c|}{ Height } \\
\cline { 2 - 6 } & $\begin{array}{c}\text { Model } \\
\text { M1 }\end{array}$ & $\begin{array}{c}\text { Model } \\
\text { M2 }\end{array}$ & $\begin{array}{c}\text { Model } \\
\text { M3 }\end{array}$ & $\begin{array}{c}\text { Model } \\
\text { M4 }\end{array}$ & $\begin{array}{c}\text { Model } \\
\text { M5 }\end{array}$ \\
\hline RT-1 & 10 & 10 & 10 & 10 & 10 \\
\hline RT & 10 & 10 & 10 & 10 & 10 \\
\hline 11F & 10 & 10 & 10 & 10 & 10 \\
\hline
\end{tabular}

\begin{tabular}{|c|c|c|c|c|c|}
\hline $10 \mathrm{~F}$ & 10 & 10 & 10 & 10 & 10 \\
\hline $9 \mathrm{~F}$ & 10 & 10 & 10 & 10 & 10 \\
\hline $8 \mathrm{~F}$ & 11 & 10 & 10 & 10 & 10 \\
\hline $7 \mathrm{~F}$ & 11 & 10 & 10 & 10 & 10 \\
\hline $6 \mathrm{~F}$ & 11 & 10 & 10 & 10 & 10 \\
\hline $5 \mathrm{~F}$ & 11 & 10 & 10 & 10 & 10 \\
\hline $4 \mathrm{~F}$ & 11 & 10 & 10 & 10 & 18 \\
\hline $3 \mathrm{~F}$ & 11 & 10 & 10 & 18 & 10 \\
\hline $2 \mathrm{~F}$ & 11 & 10 & 18 & 10 & 10 \\
\hline $1 \mathrm{~F}$ & 11 & 18 & 10 & 10 & 10 \\
\hline $\begin{array}{c}\text { GF to } \\
\text { Base }\end{array}$ & 10 & 10 & 10 & 10 & 10 \\
\hline $\begin{array}{c}\text { Total } \\
\text { height }\end{array}$ & 148 & 148 & 148 & 148 & 148 \\
\hline
\end{tabular}

Table 5. Structural element sizes

\begin{tabular}{|c|c|}
\hline Column sizes & $\begin{array}{c}22^{\prime \prime} 22 ", 20 " x 20^{\prime \prime}, 18^{\prime \prime} \times 18^{\prime \prime}, \\
16^{\prime \prime} \times 16^{\prime \prime}\end{array}$ \\
\hline $\begin{array}{c}\text { Beam sizes for } \\
\text { proposed buildings }\end{array}$ & $\begin{array}{l}18^{\prime \prime} \times 20^{\prime \prime}, 16^{\prime \prime} \times 18^{\prime \prime}, 14^{\prime \prime} \times 18^{\prime \prime}, \\
12^{\prime \prime} \times 18^{\prime \prime}, 12^{\prime \prime} \times 14 ", 10 " \times 12^{\prime \prime}\end{array}$ \\
\hline
\end{tabular}

\subsection{Model Description}

The Figure. 2 shows the architectural floor plans of proposed buildings. The Figure. 3 and Figure. 4 show the layout plan of columns and beams of all models respectively.
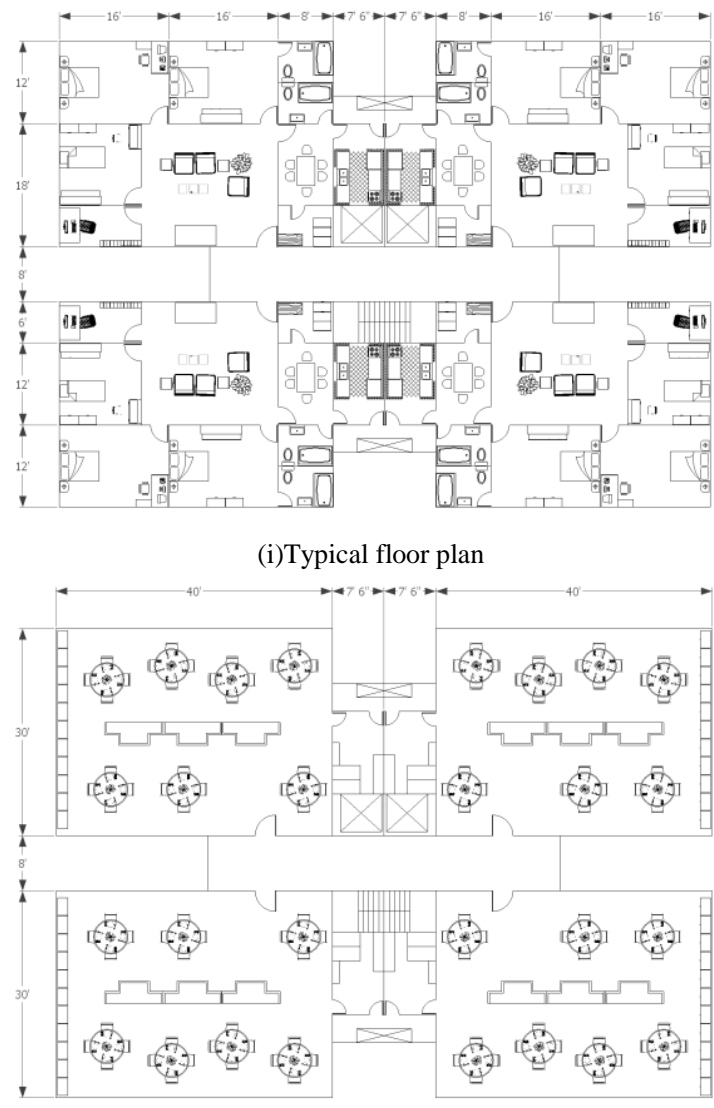

(ii)Soft storey floor plan

Figure.2 Architectural floor plan of proposed buildings 


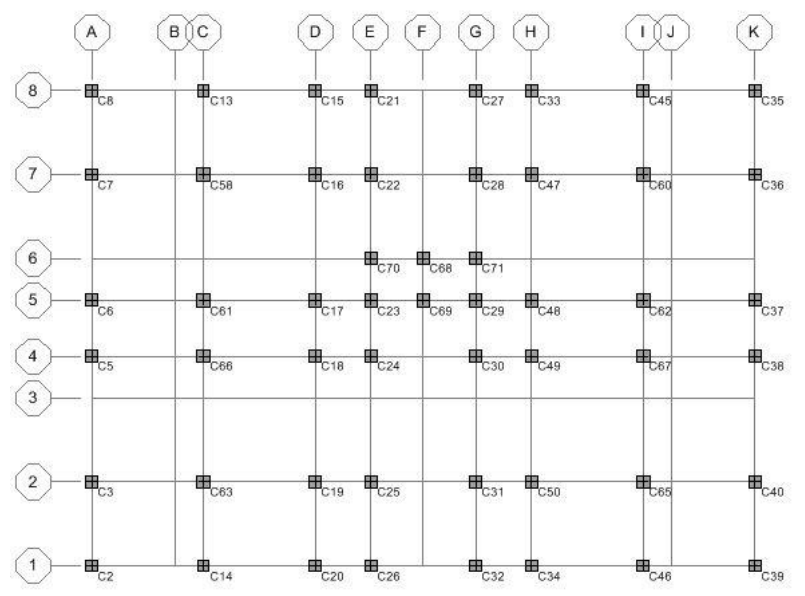

Figure.3 Typical layout plan of columns

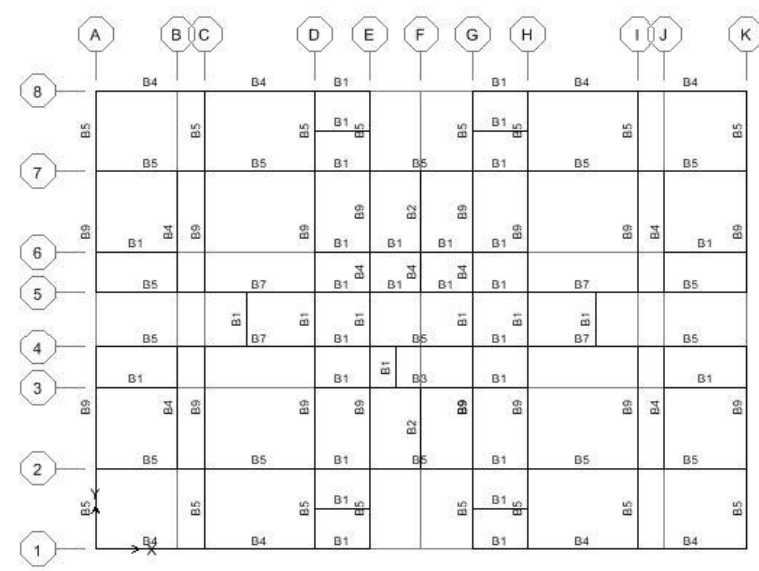

Figure.4 Typical layout plan of beams

\section{LOAD COMBINATION}

According to ACI (318-99), static design load combinations are as follows in Table 6.

Table 6. Load combination according to ACI (318-99)

\begin{tabular}{|c|c|}
\hline 1 & $1.4 \mathrm{DL}+1.4 \mathrm{SDL}$ \\
\hline 2 & $1.4 \mathrm{DL}+1.4 \mathrm{SDL}+1.7 \mathrm{LL}$ \\
\hline 3,4 & $1.05 \mathrm{DL}+1.05 \mathrm{SDL}+1.275 \mathrm{LL} \pm 1.275 \mathrm{WX}$ \\
\hline 5,6 & $1.05 \mathrm{DL}+1.05 \mathrm{SDL}+1.275 \mathrm{LL} \pm 1.275 \mathrm{WY}$ \\
\hline 7,8 & $0.9 \mathrm{DL}+0.9 \mathrm{SDL} \pm 1.3 \mathrm{WX}$ \\
\hline 9,10 & $0.9 \mathrm{DL}+0.9 \mathrm{SDL} \pm 1.3 \mathrm{WY}$ \\
\hline 11,12 & $1.05 \mathrm{DL}+1.05 \mathrm{SDL}+1.28 \mathrm{LL} \pm \mathrm{EQX}$ \\
\hline 13,14 & $1.05 \mathrm{DL}+1.05 \mathrm{SDL}+1.28 \mathrm{LL} \pm \mathrm{EQY}$ \\
\hline 15,16 & $0.9 \mathrm{DL}+0.9 \mathrm{SDL} \pm \mathrm{EQX}$ \\
\hline 17,18 & $0.9 \mathrm{DL}+0.9 \mathrm{SDL} \pm \mathrm{EQY}$ \\
\hline 19,20 & $1.27 \mathrm{DL}+1.27 \mathrm{SDL}+1.28 \mathrm{LL} \pm \mathrm{EQX}$ \\
\hline 21,22 & $1.27 \mathrm{DL}+1.27 \mathrm{SDL}+1.28 \mathrm{LL} \pm \mathrm{EQY}$ \\
\hline 23,24 & $0.68 \mathrm{DL}+0.68 \mathrm{SDL} \pm 1.02 \mathrm{EQX}$ \\
\hline 25,26 & $0.68 \mathrm{DL}+0.68 \mathrm{SDL} \pm \mathrm{EQY}$ \\
\hline
\end{tabular}

\section{RESULTS AND DISCUSSIONS}

In this section, the results obtained from the analysis of one conventional and four soft storey RC models using ETABS software have been tabulated and compared. The performance of structures on different criteria have been analyzed and discussed as follow.

\subsection{Storey Drift}

Storey drift is the lateral displacement of one level relative to the level above or below. The figure. 5 and figure. 6 show comparison of storey drift of five proposed models in $\mathrm{x}$ direction and y direction respectively. The storey drifts for models 2, 3, 4 and 5 suddenly increase at soft storey levels. From the following results, it can be seen that the storey drift of model 2 at soft storey level is maximum in both directions, the storey drift of model 3, model 4 and model 5 at that level are nearly equal in both directions and model 1 is minimum. The storey drifts in both direction at each soft storey level are more than drift limit so that the storey drift is significant in soft storey buildings.

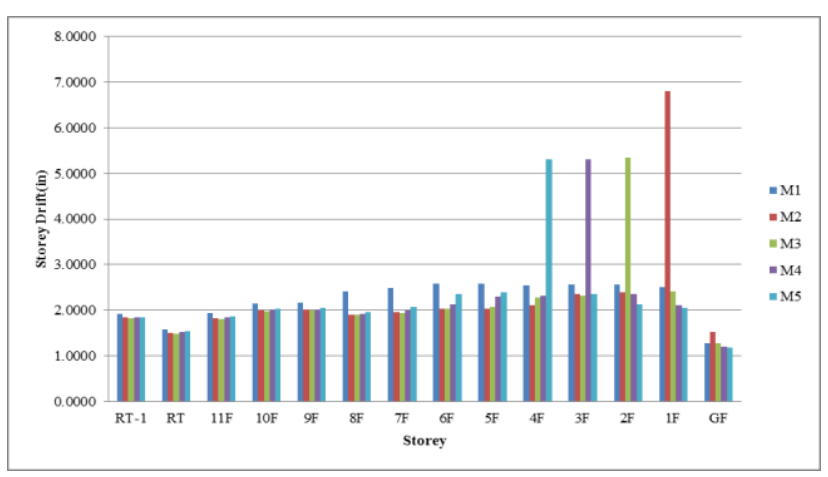

Figure.5 Comparison of storey drift in $\mathrm{x}$ direction

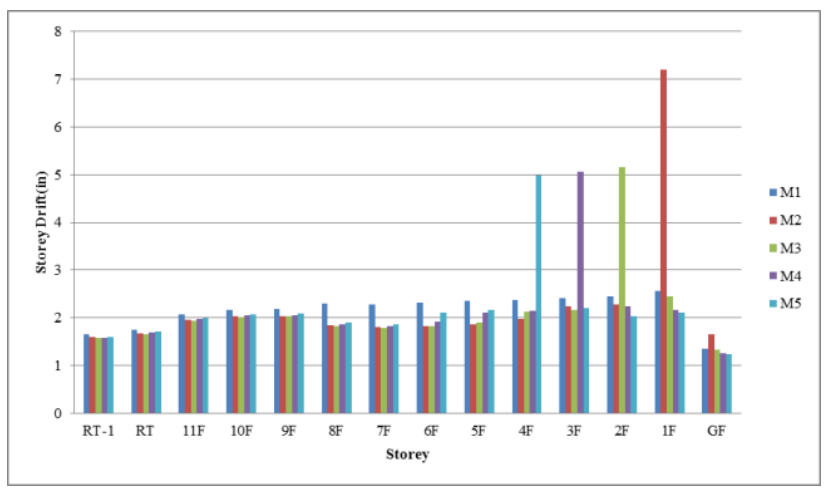

Figure.6 Comparison of storey drift in y direction

\subsection{P- $\Delta$ Effect}

The P- $\Delta$ effect results in additional forces and moments of frame members and increases storey displacement and overturning moment .The Figure. 7 and Figure. 8 show the comparison of $\mathrm{P}-\Delta$ effect in $\mathrm{x}$-direction and $\mathrm{y}$-direction respectively. In comparison of both directions, the P- $\Delta$ effects of models 2, 3, 4 and 5 suddenly increase at soft storey level in which the P- $\Delta$ effect at soft storey level of model 2 and 3 in both directions and that of model 4 in $\mathrm{X}$ direction are more 
than limitation. The stability coefficient for $\mathrm{x}$ and $\mathrm{y}$ direction of model 1 and 5 is smaller than the allowable limit (0.1). Therefore, P- $\Delta$ effect is also significant in soft storey at lower level.

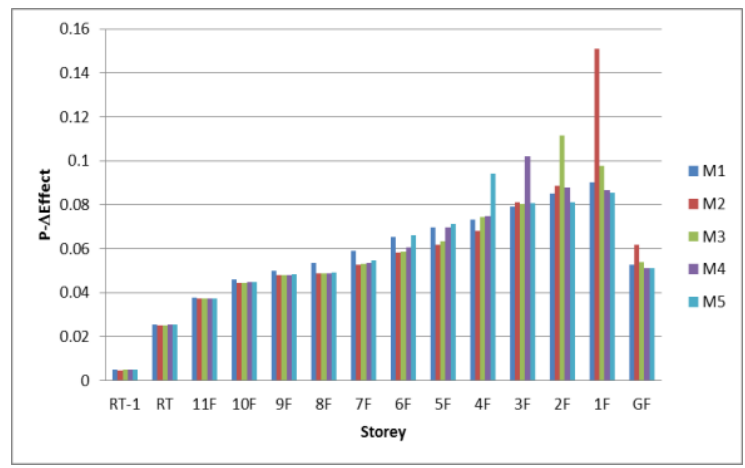

Figure.7 Comparison of P- $\Delta$ effect in $\mathrm{x}$ direction

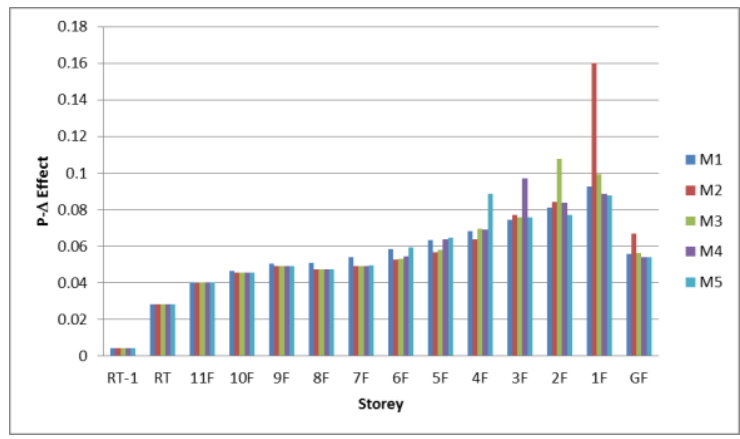

Figure.8 Comparison of P- $\Delta$ effect in y direction

\subsection{Overturning Moment}

The Figure. 9 and Figure.10 show the comparison of overturning moment in $\mathrm{x}$ direction and $\mathrm{y}$ direction. In this comparison, for all models in both directions are nearly similar and it is increasing from top to bottom.

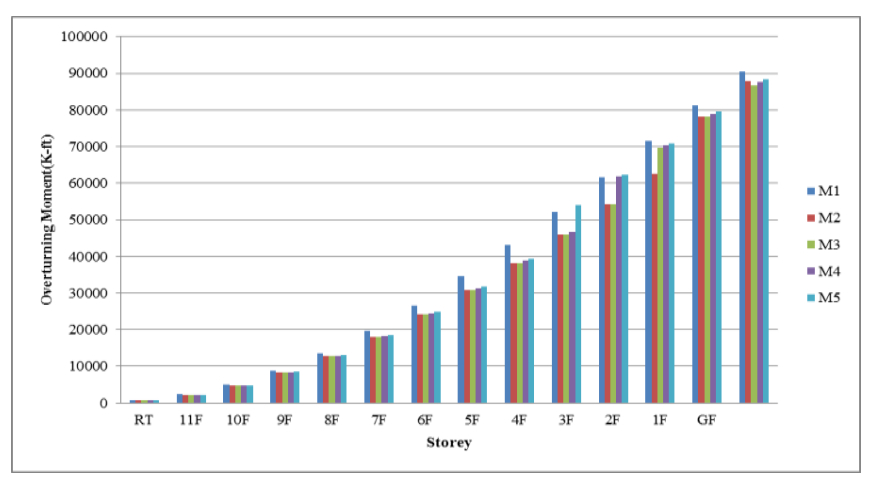

Figure. 9 Comparison of overturning moment in $\mathrm{x}$ direction

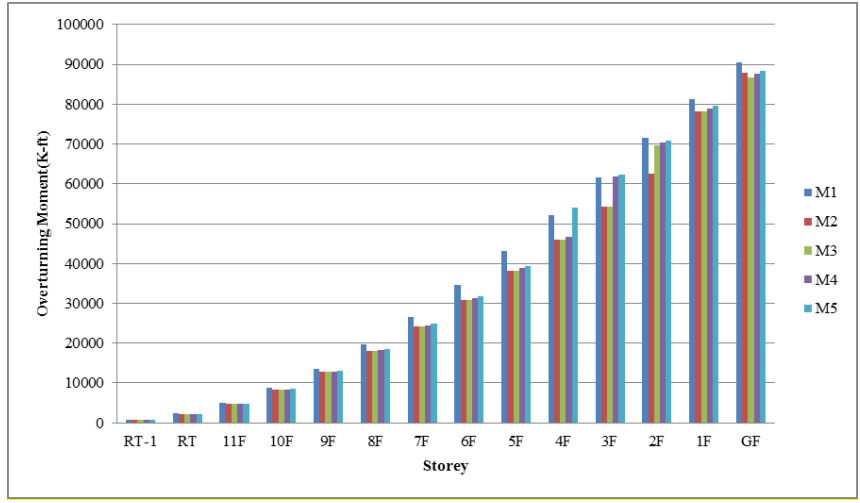

Figure.10 Comparison of overturning moment in y direction

\subsection{Storey Shear}

Storey shear is the summation of design lateral forces above the storey under consideration. The Figure.11 and Figure.12 show the comparison of storey shear in $\mathrm{x}$ direction and $\mathrm{y}$ direction. In this comparison, the results of storey shear for all models in $\mathrm{x}$ and $\mathrm{y}$ directions are nearly similar and it is increasing from top to bottom. Storey shear is the largest in footing and then it declines gradually from footing to top.

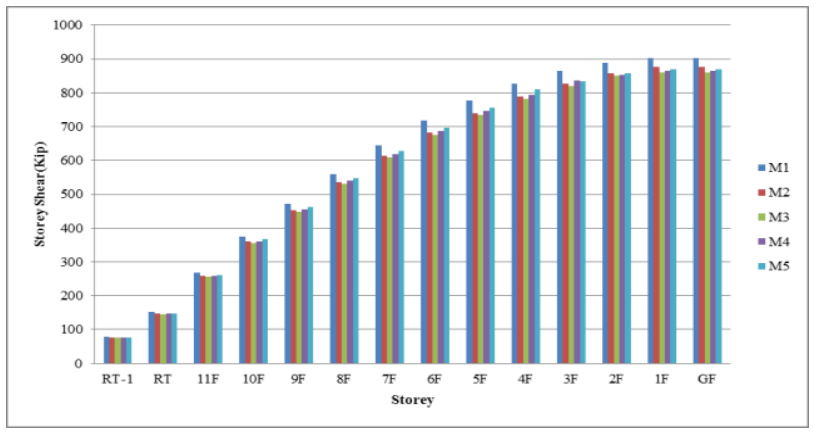

Figure.11 Comparison of storey shear in $\mathrm{x}$ direction

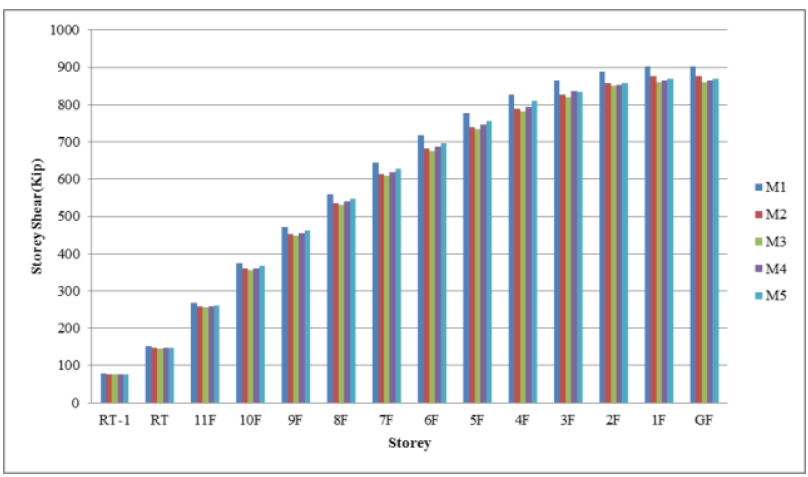

Figure.12 Comparison of storey shear in y direction

\subsection{Torsional Iirregularity}

The checking of torsional irregularity in both directions for this study is shown in Figure.13 and Figure.14. The torsional irregularity cannot exist as the values of $\Delta \mathrm{max} / \Delta \mathrm{avg}$ are smaller than the allowable limit (1.2) for all models. 


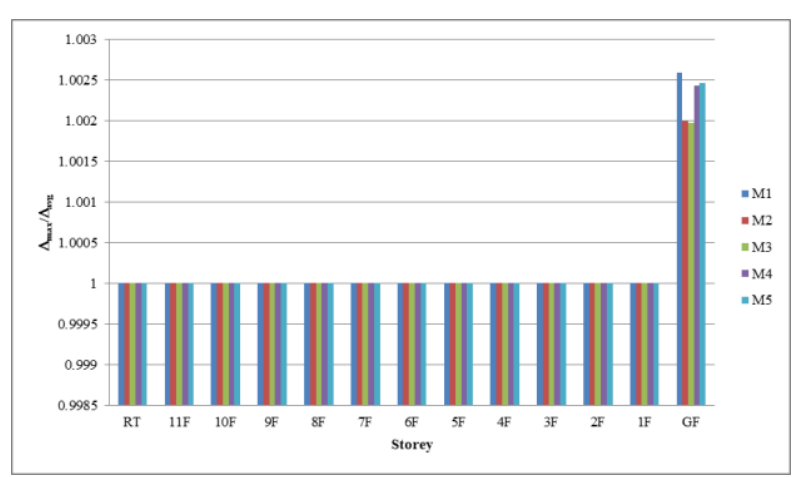

Figure.13 Comparison of $\Delta_{\max } / \Delta_{\text {avg }}$ for torsional irregularity in $\mathrm{x}$ direction

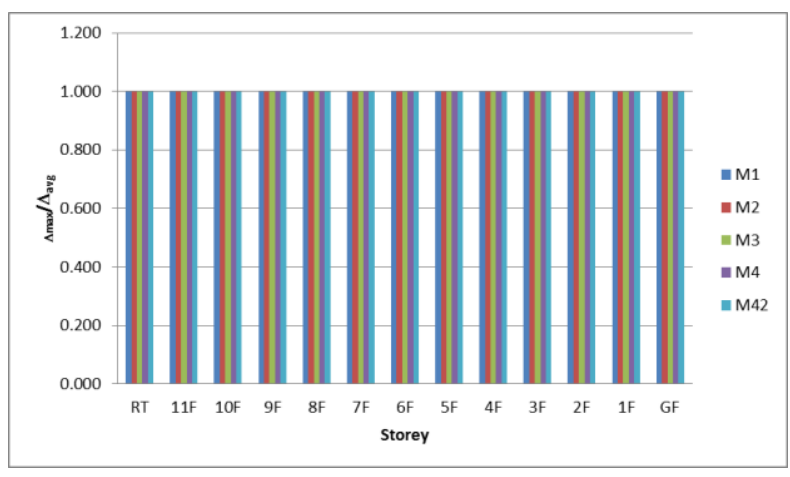

Figure.14 Comparison of $\Delta_{\max } / \Delta_{\text {avg }}$ for torsional irregularity in y direction

\section{CONCLUSION}

1. Storey drifts of soft storey models in x-direction and $y-$ direction are more than conventional building. It can be seen that the storey drift of model 2 at soft storey level is maximum in both directions. Storey drift of each soft storey level is more than drift limit and the higher the building, the more displacement will be there. Therefore, storey drift is significant in soft storey buildings.

2. P- $\Delta$ effect of model 1 and 4 are more than limitation in both directions. The stability coefficient for $\mathrm{x}$ and $\mathrm{y}$ direction of model 1 and 5 is smaller than the allowable limit in both directions. Therefore the P- $\Delta$ effect is more significant in soft storey models at low level.

3. Overturning moment of proposed models in $\mathrm{x}$-direction and y-direction are nearly similar and it is increasing from top to bottom and these safety factors are less than 1.5 .

4. The results of storey shear for all models in $\mathrm{x}$ and $\mathrm{y}$ directions are nearly similar. It is maximum at ground floor level and is gradually decreasing towards to the top storey of the structure.

5. The torsional irregularity cannot exist as the values of $\Delta \max / \Delta \mathrm{avg}$ are smaller than the allowable limit for all models.
6. According to study, overturning moment and torsional irregularity have less influence for soft storey level. However, the storey drift of model 2 at soft storey level is maximum in both directions and that of each soft storey level is more than limitation and the P- $\Delta$ effect is also significant in soft storey models at low level. Therefore, the structure is found more economical and safe when soft storey is avoided from ground, first and second storey.

\section{ACKNOWLEDGMENTS}

The author wishes to express grateful thanks to Dr. Theingi, Rector of Technological University (Thanlyin). The author wishes to express the deepest thanks and gratitude to her supervisor Dr. Kyaw Zeyar Win, Professor of Civil Engineering Department of Technological University (Thanlyin). The author special thanks go to her co-supervisor Dr. Ni Ni Moe Kyaw, Lecturer of Civil Engineering Department of Technological University (Thanlyin), for her invaluable advice and effective suggestion throughout the study. The author would like to express her thanks to her teacher Daw Ei Ei Kyaw, Assistant Lecturer of Civil Engineering Department of Technological University (Thanlyin), for her valuable comments and indispensable guidance during this study. Finally, her special thanks to all who helped her towards the successful completion of this study.

\section{REFERENCES}

[1] "International Conference of Building Officials. 1997. Uniform Building Code.Vol II”, Structural Engineering Design Provisions

[2] Murty, C.V.R. No Date "Why are Open Ground Storey Buildings Vulnerable in Earthquakes" August 2012.

[3] Dogan, Mizan, Kirac, Nevzat and Gonen, Hasan. No Date. "Soft Storey Behaviour in an Earthquake”, IZMIT - DUZCE. August 2012

[4] Weinstein. No Date. "Why Are Soft Stories Inherently Weak" August 2012

[5] "Structural Engineers Association of California.1999, Seismic Design Manual. Vol I" 